\title{
METHODS FOR DETERMINING THE TOTAL ACIDITY OF SOILS
}

\author{
By I. A. Denison
}

ABSTRACT

A method utilizing the principle of electrometric titration has been successfully applied to estimation of the total acidity of soils. Titration curves of extracts of a large group of diverse soils showed, with few exceptions, fairly well marked inflections from which the acidity of the soils could be readily estimated. The method, however, could not be applied to organic soils which absorbed much more alkali than was required to neutralize their acidity. Values obtained by two additional methods, namely, that of Hissink and that of Page and Williams agreed well with the results given by the titration method. Their use is suggested in estimating the acidity of soils, the titration curves of which do not show an inflection. The indirect method of Page and Williams, which is based on the principle of base exchange, is shown to be well adapted to measuring the acidity of organic soils.

CONTENTS

Page

I. Introduction

413

II. Review of typical methods for determining the total acidity of soils.

III. Influence of several factors on the values obtained for total acidity -

IV. Description of methods and soils studied

V. Comparison of values for total acidity by different methods....

VI. Summary

VII. Acknowledgment...

414

418

421

422

425

426

\section{INTRODUCTION}

The determination of the total acidity or the total quantity of ionizable hydrogen in soils has received much attention in recent years, and numerous methods for making this determination have been suggested. Aside from the obvious use of total acidity to indicate the quantity of lime required by an acid soil to neutralize its acidity, expressions involving total acidity, such as the ratio of hydrogen ions to the total quantity of replaceable ions absorbed by a soil are useful as a means of characterizing and differentiating soils. Recently it has been shown that the total acidity of soils has applications wholly apart from agriculture. Several investigators, including the writer, have shown that acidity is a factor in the corrosion of ferrous metals by soils. In a recent publication ${ }^{1}$ a relation is indicated between the total acidity of soils and the rate of pitting of buried specimens of iron and steel. ${ }^{1}$ A second industrial application of acidity methods is in the field of ceramics in which correlations have been obtained between the physical properties of certain clays and their base exchange capacities. ${ }^{2}$ This latter quantity corresponds to the total acidity of a clay in which all replaceable bases have been substituted by hydrogen ions.

1 Denison, I. A., Methods for Estimating the Corrosiveness of Acid Soils Toward Iron and Steel. Oil and Gas J., vol. 31, No. 19, pp. 83-87. Sept., 1932.

Unpublished data, Bureau of Standards. 


\section{REVIE.W OF TYPICAL METHODS FOR DETERMINING THE TOTAL ACIDITY OF SOILS}

Although a large number of methods have been suggested for determining the total acidity of soils, none of these methods has been generally accepted as being entirely satisfactory. The inherent difficulty in making accurate determinations of the total acidity of soils lies in the fact that the reactive materials are colloidal in nature. Since the reactions take place only on surfaces and in somewhat indefinite proportions, it is difficult to follow the course of a reaction, such as neutralization. Neutralization of the difficultly soluble acids of the soil instead of occurring instantaneously, as is the case in ordinary titrations, is apparently complete only after considerable time. Furthermore, because of effects other than neutralization, the inflections in titration curves, which are characteristic of acid-base neutralization in solutions, are usually indefinite when obtained at all, in the usual titration of soil suspensions.

Some idea of the failure of acidity methods to give concordant results when applied to soils may be obtained from the recent work of Crowther and Basu. ${ }^{3}$ In comparing the results given by nine different methods applied to eight soils, these investigators expressed the average results obtained from each method as the ratio of unsaturation ${ }^{4}$ to that given by a certain method taken as the standard. These ratios were found to vary from 0.55 to 1.02 , indicating a wide range of variation in the values obtained for acidity.

This lack of agreement in the values for acidity is due primarily to the fact that the end point of neutralization according to several methods is taken arbitrarily as "neutrality" ( $\mathrm{pH} 7$ ). In fact, Chapman and Kelley ${ }^{5}$ state that the content of replaceable $H$ ions as used by them refers to the quantity of barium hydroxide required to bring the reaction of a soil to $\mathrm{pH} 7$. Although this practice is probably justified from certain practical points of view, such as the economical application of lime to soils to neutralize their acidity, it is doubtful that the total acidity of soils can be measured by such procedure. Since the compounds formed by the neutralization of soil acids are probably salts of very weak acids, they would be expected to undergo varying degrees of hydrolysis. As a consequence, the $\mathrm{pH}$ value of a soil neutralized by a strong base must be above 7 , the exact $\mathrm{pH}$ at which the equivalence point occurs depending on the degree to which the salt formed by neutralization is hydrolyzed. Since the acidic material is subject to considerable variation in different soils, it would seem to follow that the equivalence point must likewise be subject to variation. From this point of view titration of soils to any arbitrary $\mathrm{pH}$ value would seem to be subject to serious error as a measure of the total acidity.

Although it is desirable in titrating soils to take the inflection in the titration curve as the end point of neutralization, this procedure can not be readily followed in practice, at least by the procedure ordinarily employed. The usual type of titration curve of soils shows

\footnotetext{
3 Crowther, E. M., and Basu, J. K., Studies on Soil Reaction VIII, J. Agri. Sci., vol. 21, pp. 689-715, 1931.

"The term "unsaturation" applied to the quantity of bases absorbed by solls refers to the quantity of ionizable hycirogen in a soil expressed as percentage of the total capacity of the soil to absorb exchangeable bases. A soil containing no absorbed bases other than hydrogen is 100 per cent unsaturated.

s Chapman, H. D., and Kelley, W. P., The Determination of the Replaceable Bases and the Exchange Capacity of Soils, Soil Sci., vol. 30, pp. 391-405, 1930.
} 
a constant curvature near the equivalence point, and in the absence of an inflection the end point can not, of course, be determined.

The failure of titration curves of soils to show an inflection may be considered as being due, at least in part, to the fact that soils, especially those showing marked colloidal characteristics, are capable of absorbing large quantities of alkali in excess of that required for neutralization. In fact, it has been pointed out ${ }^{6}$ that certain neutral or slightly alkaline soils may absorb much larger quantities of base than certain acid soils. In spite of this difficulty fairly pronounced inflections have been obtained by Bradfield ${ }^{7}$ and by Baver and Scarseth ${ }^{8}$ in titrating the colloidal material isolated from soils.

The failure of potentiometric methods to indicate definite end points in titrating soils led to the development of the Hissink method. ${ }^{9}$ According to this method increasing quantities of $0.1 \mathrm{~N} \mathrm{Ba}(\mathrm{OH})_{2}$ are added to definite weights of soil contained in a series of test tubes. Distilled water is then added to each tube to produce a total volume of $50 \mathrm{ml}$, the tubes are shaken occasionally over a period of three days, and allowed to stand over night. Aliquots of the clear extracts which are alkaline to phenolphthalein are then titrated with standard acid, and the results obtained plotted as ordinates against the quantities of base added as abscissas, all quantities being expressed in milliequivalents. After a few initial values a strajght line is obtained. This line is then extended to the base line and the point of intersection taken as the acidity of the soil. Values given by this method are, of course, generally higher than those obtained by titrating to $\mathrm{pH} 7$.

The fact that bases absorbed by soils may be replaced by another base present in large excess has led to the development of methods for determining total acidity based on extraction of the soil with a salt solution and titration of the replaced hydrogen in the extract. Owing to the marked buffering tiiect shown by salts of weak acids, salts, such as barium and ammonium acetates, which have been adjusted to neutrality, replace a much larger fraction of the total hydrogen than neutral salts, such as the corresponding chlorides. These methods measure the more reactive or more readily replaced hydrogen in the soils, but probably do not usually measure the total hydrogen. Methods employing extraction procedure with subsequent titration of the extract have been employed by Parker, ${ }^{10}$ Schollenberger, and Dreibelbis ${ }^{11}$ and others.

In addition to methods for determining total acidity by titrating either the soil suspended in water or a salt extract of the soil, indirect methods have been employed which do not involve titration. These methods depend on the fact that the quantity of ionizable hydrogen in a soil is equal to the difference between the total quantity of replaceable bases which the soil can absorb, expressed as equivalents, and the quantity of bases actually present. In other words, the quantity of ionizable hydrogen might be regarded as representing a

- Kelley, W. P., and Brown, S. M., Replaceable Bases in Soils, Calif. Agr. Exp. Sta. Tech. Paper 15, 1924. 7 Bradfield, R., The Saturation Capacity of Colloidal Clay Soils, Proc. First Internat. Cong. Soil Sci., vol. 4 , pp. 858-868, 1927.

8 Baver, L. D., and Scarseth, G. D., The Nature of Soil Acidity as Affected by the $\mathrm{SiO}_{2}$-sesquioxide ratio, Soil Sci., vol. 31, pp. 159-173, 1931 .

- Hissink, D. J., Base exchange in soils, Trans. Faraday Soc. vol 20, pp. 551-556, 1925.

10 Parker, F. W., Methods for the Determination of the Amount and Acidity of Exchangeable Hydrogen in Soils, Proc. First Internat. Cong. Soil Sci., vol. 2, pp. 164-173, 1927.

11 Schollenberger, C. J., and Dreibelbis, F. R., Analytical Methods in Base Exchange Investigations on Soils, Soil Sci., vol. 30, pp. 161-173, 1930.

$$
156547-33-9
$$


deficit in the total quantity of absorbed alkali and alkaline earth bases. This relation is customarily expressed by the following equation:

$$
V=100 \frac{T-S}{T}
$$

where

$V=$ degree of unsaturation of the soil with respect to replaceable bases.

$T=$ absorption capacity for exchangeable bases in milligramequivalents.

$S=$ total content of absorbed bases present in soil in milligramequivelent.

$T-S=$ absorbed hydrogen.

This principle is employed in the method of Page and Williams. ${ }^{1:}$ In determining the value, $T$, according to this method the soil is first treated with an excess of calcium carbonate in the presence of $1 \mathrm{~N}$ $\mathrm{NaCl}$. After standing for several days, the mixture is extracted with several liters of the salt solution. The hydrogen ions replaced by the sodium ions react with calcium carbonate and an equivalent amount of calcium ions pass into solution. In addition to this quantity of calcium ions, there appears in solution an additional quantity representing the calcium ions originally held by the soil in an absorbed condition. The total quantity of calcium in solution is then determined. The value, $S$, with respect to calcium, is determined by leaching a second portion of soil with sodium chloride solution, and determining the quantity of calcium in the extract as before. The difference between the values for $T$ and $S$ expressed in equivalents is taken as the total replaceable hydrogen in the soil.

It will be noted that, in determining the values $T$ and $S$ by the method just described, other absorbed bases present in soils are neglected. In practically all soils, except alkali soils, the calcium ion predominates over all others to such an extent that the values for $T$ and $S$ are only slightly lower than would be the case if the other bases were included. However, since it is the difference, $T-S$, which is of importance rather than the actual values of $T$ and $S$, neglect of the other bases is not a source of error in this method. The PageWilliams method has been studied in considerable detail by Turner. ${ }^{13} 14$

It should be noted in connection with the "difference" method which has just been described that although the capacity of many soils to absorb alkali seems practically unlimited, the capacity of these soils to absorb bases which are stoichiometrically replaceable by the base of a neutral salt solution is a definite and constant quantity. It is because of this fact that it is possible to distinguish between the quantity of base required to neutralize the acidity of a soil and the total quantity of base which a soil might absorb from an alkaline solution.

From the foregoing discussion of methods for determining the total acidity of soils, it has been seen that several of the methods, at least, do not appear to measure the total acidity of the soil but only some

13 Page, H. J., and Williams, W., Studies on base exchange in Rothamsted soils, Trans. Faraday Soc., vol. 20 , pp. $573-585,1925$.

${ }_{13}$ Turner, P. E., An Investigation of the Method of Page and Williams for the Determination of the Saturation Capacity of Soils, J. Agr. Sci., vol. 18, p. 257, 1928.

14 Turner, P. E., The State of Unsaturation of the Soil in its Relation to its Field Behavior and Lime Requirement, Soil Sci., vol. 30, pp. 349-381, 1930. 
fractional part of it, the values obtained by any one method being determined largely by the $\mathrm{pH}$ value selected as the end point of the titration. It has been seen that titration of soil suspensions to the equivalence point is rendered especially difficult by the fact that titration curves of soils do not ordinarily exhibit well-marked points of inflection. Although pronounced inflections should, perhaps, not be expected in view of the strong tendency of soils to absorb alkali, thus obscuring the break in the curve, nevertheless it would seem possible to accentuate the inflection by certain modifications in the titration procedure.

Certain factors which tend to affect the inflection in the titration curve of a soil may be listed as follows: (1) Time of contact between soil and base necessary to establish equilibrium, (2) nature of the base selected for titration, and (3) use of neutral salt solutions. It has been recognized that although the greater part of the neutralization of a soil takes place very quickly, there is a slower reaction which usually continues for some time before equilibrium is established. Slowness in attaining equilibrium is probably due in part to the fact that alkali reaches the inner surfaces of colloidal aggregates only by the slow process of diffusion. Clark and Collins, ${ }^{15}$ after an extensive study of equilibrium between soil and electrolyte, conclude that in titrating to $\mathrm{pH} 7$ with continuous shaking, 90 hours is normally required for equilibrium to be attained. Hardy and Lewis, ${ }^{16}$ on the other hand, state that little advantage is to be gained in titrating to $\mathrm{pH} 7$ if the time of continuous shaking is lengthened beyond three minutes after each increment of alkali is added.

Although values for the total acidity of soils would be expected to be identical regardless of the alkali used, it has been found that the alkaline earth hydroxides tend to give significantly higher values than the alkali hydroxides when titration is made to $\mathrm{pH} 7$. Thus Hissink and van der Spek ${ }^{17}$ found that titration curves of humus soils titrated with calcium hydroxide and sodium hydroxide had different shapes and that considerably more calcium than sodium hydroxide was required to raise the $\mathrm{pH}$ of the soils to 7 .

The use of a neutral salt solution in determining the total acidity of soils appears to possess some advantage over the use of alkali alone. The high concentration of basic ions in a normal salt solution would be expected to facilitate the attainment of equilibrium between soil and alkali by replacing hydrogen ions from the colloidal complex. Crowther and Martin ${ }^{18}$ observed that much higher values were obtained in titrating in the presence of a neutral salt than with alkali alone. The use of salt solution would also have the further effect of flocculating suspended colloidal material, thereby making possible titration of the soil extract by the colorimetric method.

The object of the present study was primarily to ascertain to what extent an inflection in the titration curve could be depended upon to indicate the end point in the titration of soils. Since it did not appear likely that the titration curves of a large number of

15 Clark, N. A., and Collins, E. R., Equilibrium Between Soil and Electroly tes, and its Influence Upon Some Lime Requirement Methods, Soil Sci., vol. 29, pp. 417-428, 1930.

${ }_{16} \mathrm{Hardy}, \mathrm{F}$., and Lewis, A. H., A Rapid Electrometric Method for Measuring Lime Requirements of Soils, J. Agr. Sci., vol. 19, pp. 18-25, 1929.

17 Hissink, D. J., and van der Spek, J., Über Titrationskurven von Humusböden, Trans. 2d Comm. Internat. Soc. Soil Sci. (Groningen), V. A. pp. 72-93, 1926.

${ }_{18}$ Crowther, E. M., and Martin, W. S., Studies on Soil Reaction VI, J. Agr. Sci., vol. 15, pp. 237-255, 1925. 
diverse soils would all show satisfactory inflections, it seemed especially desirable to ascertain whether other methods might not give satisfactory results for the acidity of those soils which did not show definite inflections. If it could be shown that values for the acidity of most soils could be determined equally well by several methods, it would be possible to substitute an alternative method in those cases where the method of direct titration could not be applied.

\section{INFLUENCE OF SEVERAL FACTORS ON THE VALUES OBTAINED FOR TOTAL ACIDITY}

Before attempting to determine the acidity of soils by the titration method, it was considered important to study the influence of the factors which have been discussed; namely, (1) time necessary to establish equilibrium between soil and alkali, (2) kind of alkali used in titration, and (3) influence of salt solution.

Estimation of the total acidity of soils was made by the method of colorimetric titration, since clear extracts would usually be produced in the normal course of the procedure to be followed. Suspensions which persisted in remaining turbid were clarified by dialysis through a collodion membrane according to the method of Pierre and Parker. ${ }^{19}$

The indicators used were those selected by Clark and Lubs ${ }^{20}$ supplemented by phthalein blue, phthalein red, and tolyl red in the higher $\mathrm{pH}$ range. The $\mathrm{pH}$ of the indicator was adjusted, according to the isohydric principle of Fawcett and Acree, ${ }^{21}$ at the acid, midpoint, and alkaline parts of its range. The difference in $\mathrm{pH}$ between indicator and test solution was seldom more than $0.2 \mathrm{pH}$ unit.

Ten gram samples of soil ground to pass a $1 \mathrm{~mm}$ sieve were placed in a series of Pyrex test tubes. Increasing amounts of $0.045 \mathrm{~N} \mathrm{Ca}$ $(\mathrm{OH})_{2}$ or $0.05 \mathrm{~N} \mathrm{NaOH}$ were then added in increments one milliequivalent of alkali per $100 \mathrm{~g}$ of soil, and the volume brought to $50 \mathrm{ml}$, with distilled water. In testing the influence of salt on the titration values, solutions of $\mathrm{NaOH}$ and $\mathrm{Ca}(\mathrm{OH})_{2}$ in $1 \mathrm{~N} \mathrm{NaCl}$ were used, a sufficient volume of $1 \mathrm{~N} \mathrm{NaCl}$ being added to bring the total volume in each tube to $50 \mathrm{ml}$. The tubes were then stoppered and shaken vigorously three times daily for periods of one and three days. The $\mathrm{pH}$ values of the extracts were then plotted against the amounts of alkali added. The neutralization point was then indicated by the inflection in the curve. Especial care was taken at all times to avoid exposing the extracts to carbon dioxide in the atmosphere.

It was usually unnecessary to construct complete titration curves, since only that part of the curve near the equivalence point is actually required. It was desirable, therefore, to form some idea of the approximate acidity of the soil before determination of the exact value was undertaken. The total acidity was roughly estimated by adding to $2 \mathrm{~g}$ samples of soil contained in test tubes, standard alkali equivalent to $5,10,15$, and 20 milliequivalents per $100 \mathrm{~g}$ of soil. A few drop of phenolpthalein were then added, the tubes shaken

10 Pierre, W. H., and Parker, F. W., The Use of Collodion Sacks in Soil Investigations. Proc. First Internat. Cong. Soil Sci., vol. 2, pp. 396-406, 1927.

${ }_{20}$ Clark, W. M., The Determination of Hydrogen Ions. The Williams \& Wilkins Co., Baltimore, Md., 1928.

${ }_{21}$ Fawcett, E. H., and Acree, S. F., The Problem of Dilution in Colorimetric H-Ion Measurements. 1. Isohydric Indicator Methods for Äccurate Determination of pH in Very Dilute Solutions. J. Bacteriology, vol. 17, pp. 163-204, 1929. 
thoroughly, and allowed to stand over night. The first tube in the series which showed a decided pink coloration was taken to indicate the approximate acidity of the soil.

The effects of kind of alkali, of time necessary to reach equilibrium, and the presence of a neutral salt, which were studied using several soils, are illustrated in Figure 1 by titration curves of a sample of Cecil clay. In studying the effect of these factors, sodium and calcium hydroxides were employed and the titration made in the presence of both distilled water and normal sodium chloride. The periods allowed for equilibrium to be established were one and three days. For the sake of clarity the curves which did not show significant differences are not shown in the figure. The curve for $\mathrm{Ca}(\mathrm{OH})_{2}$ and distilled

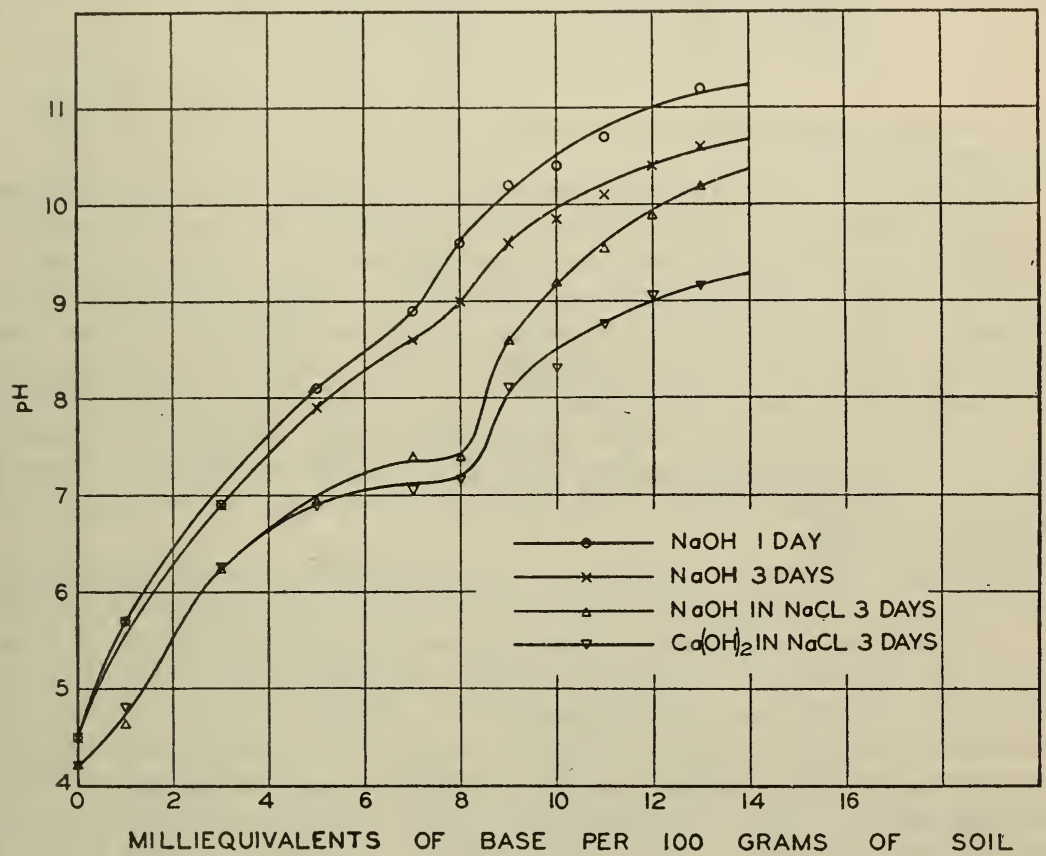

Figdre 1.-Influence of several factors on titration of Cecil clay

water, which is not shown, is similar to that for $\mathrm{Ca}(\mathrm{OH})_{2}+\mathrm{NaCl}$. Similarly, the curves for $\mathrm{Ca}(\mathrm{OH})_{2}, \mathrm{Ca}(\mathrm{OH})_{2}+\mathrm{NaCl}$, and $\mathrm{NaOH}+$ $\mathrm{NaCl}$ were practically the same for the one and three day periods.

As would probably be expected, the nature of the alkali used had no effect on the end point of the titration, although it will be observed that the $\mathrm{pH}$ values corresponding to the various concentrations of alkali are very much higher with sodium hydroxide than with the other treatments. It is evident from the table that equilibrium is not obtained with sodium hydroxide in one day. However, equilibrium was established by the other treatments within 24 hours, as previously stated. The presence of the salt solution apparently has no effect on the end point, but it does reduce very markedly the $\mathrm{pH}$ values of extracts of the soil containing sodium hydroxide. No such effect was observed in case of extracts containing calcium hydroxide. 
Relatively higher $\mathrm{pH}$ values of soil suspensions containing sodium hydroxide as compared with the hydroxides of the alkaline earths have also been observed by Hissink and Van der Spek ${ }^{22}$ and by Baver ${ }^{23}$ in their comparisons of titration curves of various alkali and alkaline earth hydroxides. The high $\mathrm{pH}$ values produced by the alkali hydroxides are considered by both Hissink and Baver to indicate that a sodium saturated clay is strongly hydrolyzed in the presence of water. The absorbed sodium ion being more highly hydrated than absorbed ions of the alkaline earths is considered to be more easily dissociated from the clay complex, and hence subject to a greater degree of hydrolysis. This effect may be represented as follows:

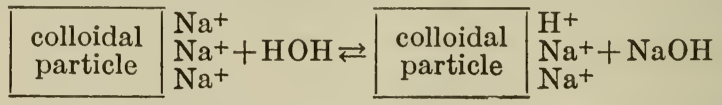

This scheme incidentally represents the process by which acidity is produced in soils.

The effect of salt solution in lowering the $\mathrm{pH}$ values of the extracts containing sodium hydroxide may be explained in part as a repression of hydrolysis by the high concentration of the salt. This tendency of a salt solution to repress the hydrolysis of an easily hydrolyzed salt has been noted by Jenny ${ }^{24}$ in titrating aluminum chloride with sodium hydroxide. It was found that the presence of both sodium and potassium chlorides lowered considerably the $\mathrm{pH}$ values of the solution as titration proceeded. The assumption that calcium saturated clays are not subject to marked hydrolysis would explain the absence of any appreciable effect of the presence of salt in titrating with calcium hydroxide.

Although satisfactory results in titrating soils can apparently be obtained with either sodium or calcium hydroxides and with or without salt solution, providing sufficient time for establishment of equilibrium is allowed, a standard solution of $0.05 \mathrm{Na}(\mathrm{OH})_{2}$ in $1 \mathrm{~N}$ $\mathrm{NaCl}$ was chosen for determination of acidity. Since one of the alternative methods to be employed required the use of calcium carbonate and sodium chloride, it was considered advisable to maintain a similar anionic and cationic system in the titration procedure. Although the preliminary work did not indicate that a titration period greater than 24 hours was necessary in the case of the soils studied, it was considered desirable in the light of the experience of certain other investigators to allow three days for equilibrium to be established. The use of calcium hydroxide and sodium chloride insured rapid flocculation of the soil particles, thereby making possible titra tion of the extracts by the colorimetric method.

\footnotetext{
22 See footnote 17, p. 417 .

${ }_{23}$ Baver, L. D. Relation of the Amount and Nature of Exchangeable Cations to the Structure of Colloidal Clay, Soil Sci., vol. 29, pp. 291-308, 1930.

"Jenny, H., Behavior of Potassium During the Process of Soil Formation, Res. Bull. 162, Mo. Agr. Exp. Sta., 1931 .
} 


\section{DESCRIPTION OF METHODS AND SOILS STUDIED}

The methods used in determining the total acidity of the soils selected for study were: (1) Colorimetric titration of the soils by $0.05 \mathrm{~N} \mathrm{Ca}(\mathrm{OH})_{2}$ in the presence of $1 \mathrm{~N} \mathrm{NaCl}$, allowing 72 hours contact between alkali and soil. The details of this method have been previously given. (2) The Hissink method modified to include the use of salt solution and by substitution of $0.05 \mathrm{~N} \mathrm{Ca}(\mathrm{OH})_{2}$ for $0.1 \mathrm{~N}$ $\mathrm{Ba}(\mathrm{OH})_{2}$. (3) The modified "difference" method of Page and Williams. The principle of this method and an outline of the procedure have been previously given. This latter method would seem to be particularly well adapted to measurement of the acidity of highly absorptive organic soils. Because of the fact that such soils are especially well buffered in the alkaline range it is not likely that a titration curve would show an inflection from which their values for acidity could be determined.

The details of the procedure followed in determining acidity by the "difference" method are as follows. The capacity of the soil to absorb exchangeable bases ( $\mathrm{T}$ ) was first determined. A $25 \mathrm{~g}$ sample of soil was placed in a $250 \mathrm{ml}$ Erlenmeyer flask, about $1 \mathrm{~g}$ of calcium carbonate added, the soil treated with 150 to $200 \mathrm{ml}$ of $1 \mathrm{~N} \mathrm{NaCl}$ which had been heated to $80^{\circ}$ to $90^{\circ} \mathrm{C}$., and the mixture maintained near that temperature for one hour with occasional shaking. The mixture was then poured into a $400 \mathrm{ml}$ bottle, shaken over night in an endover-end shaker and also for 2-hour periods on two succeeding days. After standing over night the extract was decanted and filtered into a 1 liter beaker. A $200 \mathrm{ml}$ portion of salt solution was then added to the soil, the mixture shaken an hour, allowed to settle, and the extract decanted through the filter as before. This process was repeated until 1 liter of extract was obtained. For the final filtration the entire quantity of soil was poured on the filter and washed. The extract was then mixed thoroughly and the calcium present in a 400 $\mathrm{ml}$ portion was determined gravimetrically. From the value thus obtained, the quantity of calcium equivalent to the solubility of calcium carbonate in 1 liter of $1 \mathrm{~N} \mathrm{NaCl}$ was subtracted.

The quantity of replaceable calcium present in the soil $(S)$ was determined in a manner which was similar to the determination of the exchangeable base capacity, except that no calcium carbonate was added and the shaking was limited to 18 hours. In the case of those soils in which calcium carbonate occurred naturally, a correction was made for the calcium which had been dissolved as carbonate by the salt solution. This quantity was calculated from the amount of bicarbonate in solution, which was estimated by titrating an aliquot portion of the extract with standard acid to the color change of methyl orange.

The quantity of exchangeable hydrogen or the total acidity of the soil $(T-S)$ was obtained by subtracting from the exchange capacity of the soil the adsorbed calcium found to be present.

The soils selected for study were those in which the test sites of the Bureau of Standards soil-corrosion investigation are located and are described in a previous paper. ${ }^{25}$ These soils are diverse in character,

\footnotetext{
2 Logan, K. H., Ewing, S. P., and Yeomans, C. D., Bureau of Standards Soil Corrosion Studies 1. Soils,
} materials and results of early observations Tech. Paper No. $368,1928$. 
representing a wide range of texture, parent material, stage of development and geographic distribution. The soils studied, together with their locations are listed in Table 1 , in which the values for acidity are shown.

\section{COMPARISON OF VALUES FOR TOTAL ACIDITY BY DIFFERENT METHODS}

The method of colorimetric titration produced fairly well-marked inflections in the titration curves of the majority of the soils studied. As may be seen from Table 1 definite values for acidity by means of titration curves were obtained in the case of all soils except five. Of

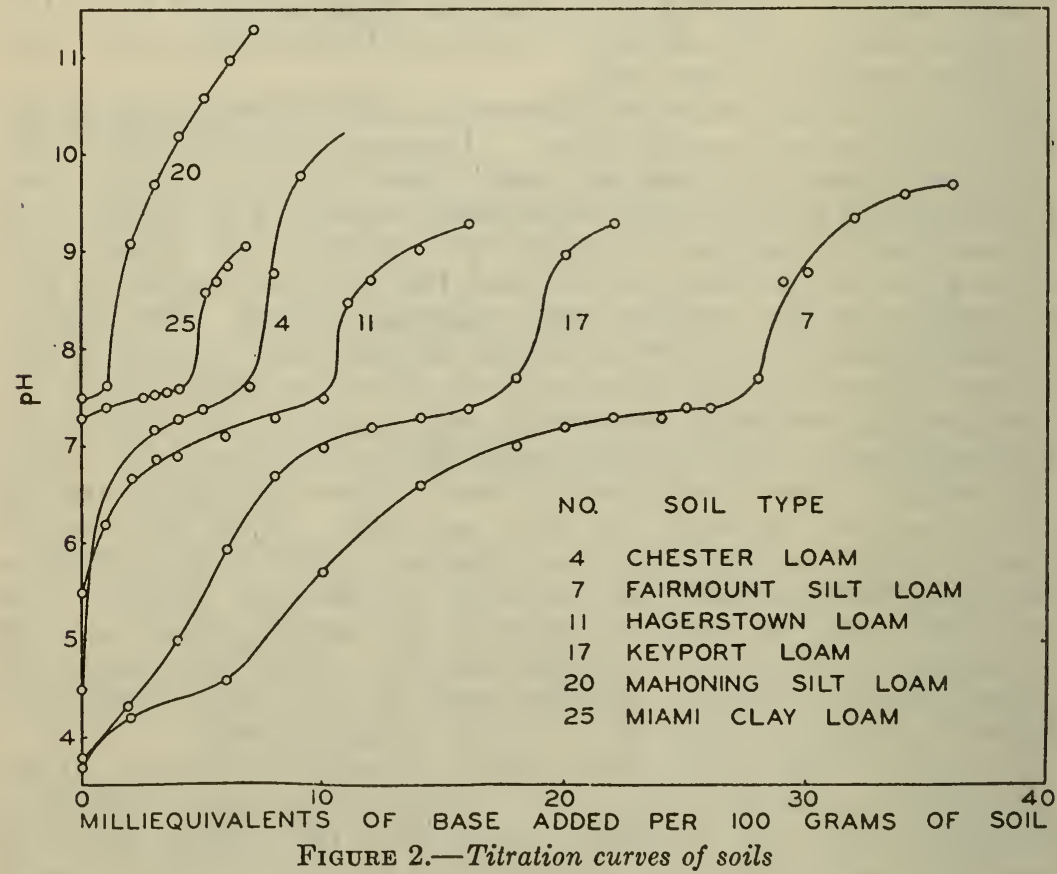

this number, three soils, namely, the muck, peat, and tidal marsh, are organic and apparently have an unlimited capacity for absorbing alkali. In the case of several soils it was necessary to estimate the position of the end point by extending the convex and concave portion of the curve and locating the end point on the curve between these extensions. Curves typical of those in which distinct inflections occurred are shown in Figure 2. The results shown in the figure are expressed as milliequivalents of hydrogen per $100 \mathrm{~g}$ of air-dry soil. It should be pointed out that the soil designated in Figure 2 and in Table 1 as Fairmount was incorrectly classified, since soils of the Fairmount series are alkaline below the surface horizon.

It is of interest to note in connection with Figure 2, that the values for acidity obtained by titrating to $\mathrm{pH} 7$, as required by some methods, 
are approximately one-half as large as those obtained by titrating to an inflection in the curve.

Typical curves obtained by the modified Hissink method are shown in Figure 3. In certain of the curves not shown in the drawing the slopes of straight line connecting the points were much less than those shown in the table. An especially slight slope would seem to indicate market absorption of alkali in excess of that required for neutralization.

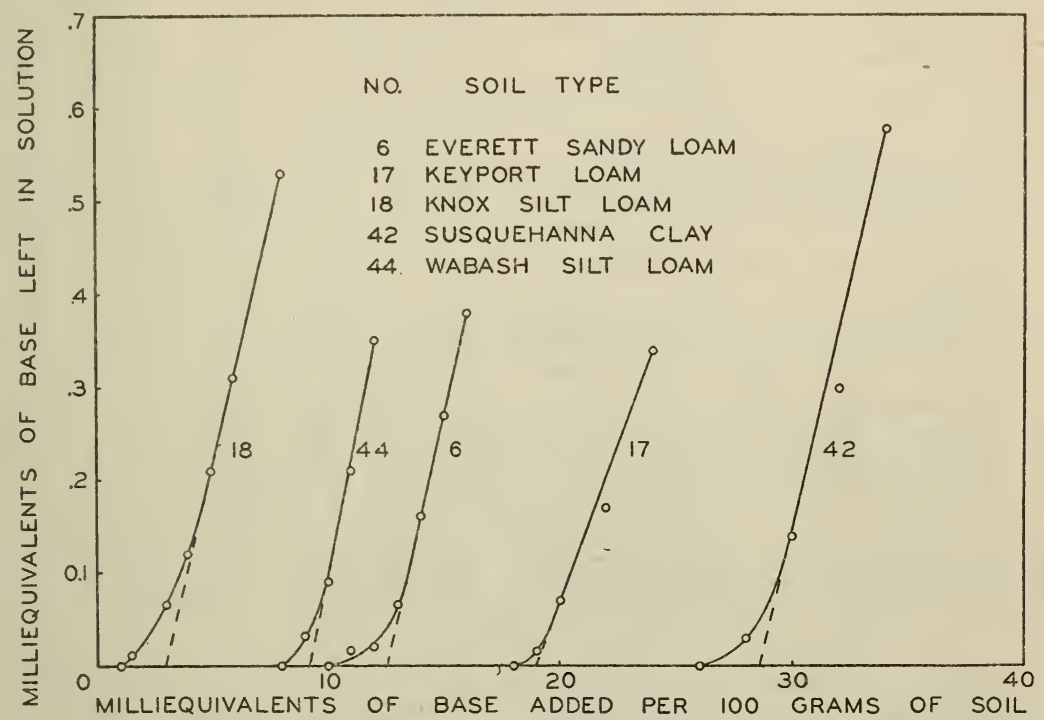

FIGURE 3.-Titration curves of soils (modified Hissink method)

The values obtained by the method of colorimetric titration, by the modified Hissink method, and by the modified Page and Williams method are shown in Table 1 . The differences between the values obtained by the Hissink and the Page Williams methods as compared with those given by the titration method are also shown in the table. All values are based on the weight of the soil dried in the oven at $105^{\circ} \mathrm{C}$. 
TABLE 1.-Comparison of values for total acidity obtained by different methods

\begin{tabular}{|c|c|c|c|c|c|c|c|c|c|}
\hline \multirow[b]{2}{*}{$\begin{array}{l}\text { Soil } \\
\text { No. }\end{array}$} & \multirow[b]{2}{*}{ Soil type } & \multirow[b]{2}{*}{ Location } & \multirow[b]{2}{*}{ Depth } & \multirow[b]{2}{*}{$\begin{array}{l}\mathrm{pH} \text { of } \\
\text { soil } 1\end{array}$} & \multicolumn{3}{|c|}{ Total acidity } & \multicolumn{2}{|c|}{ Differences } \\
\hline & & & & & $\begin{array}{l}\text { (1) } \\
\text { Titra- } \\
\text { tion } \\
\text { curve }\end{array}$ & $\begin{array}{c}(2) \\
\text { Modi- } \\
\text { fied His- } \\
\text { sink } \\
\text { method }\end{array}$ & $\begin{array}{l}\text { (3) } \\
\text { Page- } \\
\text { Wil- } \\
\text { liams } \\
\text { method }\end{array}$ & $\begin{array}{l}\text { Meth- } \\
\text { ods } 1 \\
\text { and } 2\end{array}$ & $\begin{array}{l}\text { Meth- } \\
\text { ods 1 } \\
\text { and 3 }\end{array}$ \\
\hline $\begin{array}{r}1 \\
2 \\
3 \\
104 \\
105\end{array}$ & $\begin{array}{l}\text { Allis silt loam } \\
\text { Bell clay } \\
\text { Cecil clay loam } \\
\text { Cecil clay } \\
\text { Cecil clay loam. }\end{array}$ & $\begin{array}{l}\text { Cleveland, Ohio } \\
\text { Dallas, Tex } \\
\text { Atlanta, Ga } \\
\text { Charlotte, N. C.. } \\
\text { Macon, Ga... }\end{array}$ & $\begin{array}{c}\text { Inches } \\
90 \\
40 \\
32 \\
36 \\
30\end{array}$ & $\begin{array}{l}7.0 \\
7.3 \\
5.2 \\
4.6 \\
4.8\end{array}$ & $\begin{array}{r}M . e .{ }^{2} \\
11.4 \\
3.5 \\
11.5 \\
11.0 \\
12.9\end{array}$ & $\begin{array}{r}M . e . \\
11.2 \\
7.5 \\
11.5 \\
10.8 \\
12.8\end{array}$ & $\begin{array}{r}M . e . \\
7.9 \\
2.3 \\
10.8 \\
10.7 \\
11.7\end{array}$ & $\begin{array}{c}\text { M.e. } \\
-0.2 \\
+4.0 \\
0 \\
-.2 \\
-.1\end{array}$ & $\begin{array}{r}M . e . \\
-3.5 \\
-1.2 \\
-.7 \\
-.3 \\
-1.2\end{array}$ \\
\hline $\begin{array}{r}106 \\
107 \\
108 \\
4 \\
5\end{array}$ & $\begin{array}{l}\text { Cecil fine sandy loam } \\
\text { Cecil gravelly loam } \\
\text { Chester loam } \\
\text { Dublin clay adobe. }\end{array}$ & $\begin{array}{l}\text { Salisbury, N. C... } \\
\text { Raleigh, N. C.... } \\
\text { Atlanta, Ga.... } \\
\text { Jenkintown, Pa.. } \\
\text { Oakland, Calif... }\end{array}$ & $\begin{array}{l}36 \\
30 \\
30 \\
36 \\
30\end{array}$ & $\begin{array}{l}4.8 \\
4.8 \\
4.9 \\
5.6 \\
7.0\end{array}$ & $\begin{array}{r}12.8 \\
11.8 \\
11.2 \\
7.6 \\
7.5\end{array}$ & $\begin{array}{r}12.8 \\
12.8 \\
11.7 \\
7.3 \\
6.5\end{array}$ & $\begin{array}{r}10.6 \\
10.4 \\
10.7 \\
6.9 \\
6.4\end{array}$ & $\begin{array}{r}0 \\
+1.0 \\
+.5 \\
-.3 \\
-1.0\end{array}$ & $\begin{array}{l}-2.2 \\
-1.4 \\
-.5 \\
-.7 \\
-1.1\end{array}$ \\
\hline 6 & $\begin{array}{l}\text { Everett gravelly sandy } \\
\text { loam. }\end{array}$ & Seattle, Wash & 36 & 5. 9 & 12.8 & 12.8 & 12.5 & 0 & -.3 \\
\hline $\begin{array}{r}7 \\
9 \\
10 \\
11\end{array}$ & $\begin{array}{l}\text { Fairmount silt loam } \\
\text { Genesee silt loam } \\
\text { Gloucester sandy loam } \\
\text { Hagerstown loam }\end{array}$ & $\begin{array}{l}\text { Cincinnati, Ohio.. } \\
\text { Sidney, Ohio } \\
\text { Middleboro, Mass } \\
\text { Baltimore, Md... }\end{array}$ & $\begin{array}{l}40 \\
22 \\
30 \\
60\end{array}$ & $\begin{array}{l}4.4 \\
6.8 \\
6.6 \\
5.3\end{array}$ & $\begin{array}{r}31.3 \\
(3) \\
3.6 \\
10.8\end{array}$ & $\begin{array}{r}33.0 \\
7.0 \\
4.8 \\
11.1\end{array}$ & $\begin{array}{r}26.9 \\
.3 \\
2.7 \\
10.5\end{array}$ & $\begin{array}{r}+1.7 \\
+1.2 \\
+.3\end{array}$ & $\begin{array}{r}-4.4 \\
-.9 \\
-.3\end{array}$ \\
\hline $\begin{array}{l}12 \\
14 \\
15 \\
16 \\
17\end{array}$ & $\begin{array}{l}\text { Hanford fine sandy loam } \\
\text { Hempstead silt loam..... } \\
\text { Houston black clay } \\
\text { Kalmia fine sandy loam... } \\
\text { Keyport loam }\end{array}$ & $\begin{array}{l}\text { Los Angeles, Calif } \\
\text { St. Paul, Minn... } \\
\text { San Antonio, Tex } \\
\text { Mobile, Ala, } \\
\text { Alexandria, Va.... }\end{array}$ & $\begin{array}{l}24 \\
60 \\
36 \\
30 \\
36\end{array}$ & $\begin{array}{l}7.1 \\
6.2 \\
7.5 \\
4.4 \\
4.5\end{array}$ & $\begin{array}{r}2.5 \\
5.6 \\
5.0 \\
11.8 \\
19.1\end{array}$ & $\begin{array}{r}2.0 \\
5.5 \\
5.0 \\
11.7 \\
19.5\end{array}$ & $\begin{array}{r}2.3 \\
7.2 \\
3.0 \\
14.0 \\
19.8\end{array}$ & $\begin{array}{l}-.5 \\
-.1 \\
0 \\
-.1 \\
+.4\end{array}$ & $\begin{array}{r}-.2 \\
+1.6 \\
-2.0 \\
+2.2 \\
+.7\end{array}$ \\
\hline $\begin{array}{l}18 \\
19 \\
20 \\
21 \\
22\end{array}$ & $\begin{array}{l}\text { Knox silt loam } \\
\text { Lindley silt loam } \\
\text { Mahoning silt loam } \\
\text { Marshall silt loam } \\
\text { Memphis silt loam }\end{array}$ & $\begin{array}{l}\text { Omaha, Nebr } \\
\text { Des Moines, Iowa } \\
\text { Cleveland, Ohio.. } \\
\text { Kansas City, Mo } \\
\text { Memphis, Tenn }\end{array}$ & $\begin{array}{l}48 \\
36 \\
50 \\
36 \\
33\end{array}$ & $\begin{array}{l}7.3 \\
4.6 \\
7.5 \\
6.2 \\
4.9\end{array}$ & $\begin{array}{r}1.4 \\
10.9 \\
1.5 \\
9.5 \\
12.8\end{array}$ & $\begin{array}{r}3.1 \\
10.9 \\
1.8 \\
9.0 \\
11.5\end{array}$ & $\begin{array}{r}3.1 \\
10.7 \\
1.7 \\
10.4 \\
9.3\end{array}$ & $\begin{array}{l}+1.7 \\
0 \\
+.3 \\
-.5 \\
-1.3\end{array}$ & $\begin{array}{r}+1.7 \\
-.2 \\
-.2 \\
+.9 \\
-3.5\end{array}$ \\
\hline $\begin{array}{r}115 \\
24 \\
25 \\
26 \\
27\end{array}$ & $\begin{array}{l}\text { Merrimac gravelly sandy } \\
\text { Miami clay loam } \\
\text { Miami silt loam } \\
\text { Miller clay }\end{array}$ & $\begin{array}{l}\text { Vicksburg, Miss. } \\
\text { Norwood, Mass.-. } \\
\text { Milwaukee, Wis. } \\
\text { Springfield, Ohio. } \\
\text { Bunkie, La...... }\end{array}$ & $\begin{array}{l}30 \\
33 \\
36 \\
48 \\
30\end{array}$ & $\begin{array}{l}6.9 \\
4.5 \\
7.2 \\
7.3 \\
6.6\end{array}$ & $\begin{array}{r}4.7 \\
12.6 \\
4.7 \\
2.6 \\
3.7\end{array}$ & $\begin{array}{r}5.9 \\
13.1 \\
4.8 \\
3.8 \\
4.8\end{array}$ & $\begin{array}{r}3.6 \\
15.7 \\
3.0 \\
2.7 \\
3.5\end{array}$ & $\begin{array}{r}+1.2 \\
+.5 \\
+.2 \\
+1.2 \\
+1.1\end{array}$ & $\begin{array}{l}-1.1 \\
+3.1 \\
-1.7 \\
+.1 \\
-.2\end{array}$ \\
\hline $\begin{array}{r}29 \\
30 \\
31 \\
121 \\
119\end{array}$ & $\begin{array}{l}\text { Muck } \\
\text { Muscatine silt loam } \\
\text { Norfolk sand } \\
\text { Norfolk sandy loam }\end{array}$ & $\begin{array}{l}\text { New Orleans, La } \\
\text { Davenport, Iowa. } \\
\text { Jacksonville, Fla.. } \\
\text { Tampa, Fla...... } \\
\text { Macon, Ga....... }\end{array}$ & $\begin{array}{l}24 \\
36 \\
24 \\
24 \\
30\end{array}$ & $\begin{array}{l}4.2 \\
7.0 \\
4.7 \\
4.8 \\
4.7\end{array}$ & $\begin{array}{l}\text { (4) } \\
2.6 \\
1.8 \\
1.2 \\
9.7\end{array}$ & $\begin{aligned}(4) \\
2.7 \\
1.8 \\
1.3 \\
10.7\end{aligned}$ & $\begin{array}{r}26.8 \\
1.0 \\
2.0 \\
2.6 \\
9.7\end{array}$ & $\begin{array}{r}+.1 \\
0 \\
+.1 \\
+1.0\end{array}$ & $\begin{array}{r}-1.6 \\
+.2 \\
+1.4 \\
0\end{array}$ \\
\hline $\begin{array}{r}120 \\
32 \\
33 \\
34 \\
35\end{array}$ & $\begin{array}{l}\text { Ontario loam } \\
\text { Peat. } \\
\text { Penn silt loam } \\
\text { Ramona loam }\end{array}$ & $\begin{array}{l}\text { Pensacola, Fla } \\
\text { Rochester, N. Y } \\
\text { Milwaukee, Wis. } \\
\text { Norristown, Pa } \\
\text { Los Angeles, Calif }\end{array}$ & $\begin{array}{l}36 \\
48 \\
24 \\
34 \\
36\end{array}$ & $\begin{array}{l}5.7 \\
7.3 \\
6.8 \\
6.7 \\
7.3\end{array}$ & $\begin{array}{l}1.3 \\
.5 \\
(4)^{5} \\
7.0 \\
5.7\end{array}$ & $\begin{array}{r}1.3 \\
2.4 \\
(4) \\
7.1 \\
5.6\end{array}$ & $\begin{array}{r}1.4 \\
1.1 \\
33.0 \\
4.4 \\
2.9\end{array}$ & \begin{tabular}{c}
0 \\
+1.9 \\
\hdashline+.1 \\
-.1
\end{tabular} & $\begin{array}{l}+.1 \\
+.6 \\
-2.6 \\
-2.8\end{array}$ \\
\hline $\begin{array}{l}36 \\
37 \\
38\end{array}$ & $\begin{array}{l}\text { Ruston sandy loam } \\
\text { St. Johns fine sand } \\
\text { Sassafras gravelly sandy }\end{array}$ & $\begin{array}{l}\text { Meridian, Miss.. } \\
\text { Jacksonville, Fla. } \\
\text { Camden, N. J... }\end{array}$ & $\begin{array}{l}36 \\
30 \\
30\end{array}$ & $\begin{array}{l}4.5 \\
3.8 \\
4.5\end{array}$ & $\begin{array}{l}4.6 \\
(4) \\
1.7\end{array}$ & $\begin{array}{c}4.9 \\
(4) \\
2.1\end{array}$ & $\begin{array}{r}7.3 \\
15.3 \\
3.2\end{array}$ & $\begin{array}{l}-.3 \\
+.4\end{array}$ & $\begin{array}{l}+2.7 \\
+1.5\end{array}$ \\
\hline $\begin{array}{l}39 \\
40\end{array}$ & $\begin{array}{l}\text { Sassafras silt loam } \\
\text { Sharkey clay.... }\end{array}$ & $\begin{array}{l}\text { Wilmington, Del. } \\
\text { New Orleans, La. }\end{array}$ & $\begin{array}{l}36 \\
30\end{array}$ & $\begin{array}{l}5.6 \\
6.0\end{array}$ & $\begin{array}{l}\text { 6. } 6 \\
(3)\end{array}$ & $\begin{array}{l}7.9 \\
9.4\end{array}$ & $\begin{array}{l}6.6 \\
9.2\end{array}$ & $\begin{array}{l}+1.3 \\
-\ldots\end{array}$ & 0 \\
\hline $\begin{array}{r}41 \\
42 \\
123 \\
124\end{array}$ & $\begin{array}{l}\text { Summit silt loam } \\
\text { Susquehanna clay }\end{array}$ & $\begin{array}{l}\text { Kansas City, Mo } \\
\text { Meridian, Miss... } \\
\text { Shreveport, La... } \\
\text { Troup, Tex...... }\end{array}$ & $\begin{array}{l}36 \\
30 \\
30 \\
36\end{array}$ & $\begin{array}{l}5.5 \\
4.7 \\
4.1 \\
4.4\end{array}$ & $\begin{array}{l}11.0 \\
28.2 \\
21.9 \\
28.1\end{array}$ & $\begin{array}{l}12.6 \\
30.3 \\
22.4 \\
29.2\end{array}$ & $\begin{array}{l}11.1 \\
31.9 \\
(4) \\
25.0\end{array}$ & $\begin{array}{r}+1.6 \\
+2.1 \\
+.5 \\
+1.1\end{array}$ & $\begin{array}{r}+.1 \\
+3.7 \\
\hdashline-3.1\end{array}$ \\
\hline 125 & Susquehanna fine sandy & Shreveport, La. & 42 & 3.9 & 28.3 & 28.8 & 28.3 & +.5 & 0 \\
\hline $\begin{array}{l}43 \\
44 \\
47\end{array}$ & $\begin{array}{l}\text { Tidal marsh } \\
\text { Wabash silt loam } \\
\text { Unidentified silt loam }\end{array}$ & $\begin{array}{l}\text { Elizabeth, N. J.. } \\
\text { Omaha, Nebr } \\
\text { Salt Lake City, } \\
\text { Utah. }\end{array}$ & $\begin{array}{l}36 \\
30 \\
36\end{array}$ & $\begin{array}{l}3.1 \\
5.8 \\
7.6\end{array}$ & $\begin{array}{l}\text { (4) } \\
8.8 \\
3.0\end{array}$ & $\begin{array}{l}(\stackrel{4}{ }) \\
9.5 \\
2.8\end{array}$ & $\begin{array}{r}34.8 \\
9.3 \\
3.7\end{array}$ & $\begin{array}{l} \pm .7 \\
-.2\end{array}$ & $\begin{array}{l}+.5 \\
+.7\end{array}$ \\
\hline & & & & & 9.4 & 9.8 & 10.0 & 0.67 & 1. 30 \\
\hline
\end{tabular}

1 Determined colorimetrically in $1: 2$ soil-water ex tract.

3 Milliequivalents per 100 grams of soil.

${ }^{3}$ No definite inflection in titration curve.

- Not determined. 
Comparison of the three sets of values shown in the table indicates that the three methods for determining acidity give substantially the same results. The agreement between the values given by the method of colorimetric titration and the modified Hissink method is with two exceptions less than $2 \mathrm{~m}$. e. per $100 \mathrm{~g}$ of soil. The large error of $4 \mathrm{~m}$. e. which occurred in the case of the Bell clay is to be ascribed to the high buffering capacity of this soil immediately above its equivalence point. Because of marked absorption of alkali beyond that required for neutralization, the excess of alkali added in titrating this soil could not be detected by titrating with acid until the equivalence point had been passed.

If the values given by the difference method are compared with those obtained from the titration curve, it will be observed that in spite of the obvious dissimilarity in the two methods, the agreement is generally satisfactory. In approximately 80 per cent of the total number of results the agreement is within $2 \mathrm{~m}$. e. per $100 \mathrm{~g}$ of soil. The errors in the difference method are apparently unaffected by the quantity of acid in the soil, but analysis of the data suggests that lower values for acidity by the difference method are slightly more numerous in the heavy clay soils. This is to be expected owing to the difficulty of completely removing absorbed ions from such soils.

From the fact that the results obtained by the three methods under study are in substantial agreement, it seems reasonable to conclude that failure to obtain a satisfactory inflection in the titration curve of a soil does not necessitate the selection of some arbitrary $\mathrm{pH}$ value as the end point of neutralization. In determining the acidity of those soils whose titration curves show an uncertain inflection or none at all, it would seem preferable to employ an alternative method. The method best adapted to estimate the acidity of organic soils and other soils especially well buffered in the alkaline range is preferably based on the principle of base exchange. The "difference" method which has been described is well adapted to such soils. Regardless of the capacity of soils to absorb bases, the base exchange capacity is a definite and determinable quantity.

\section{SUMMARY}

1. Titration of soil extracts to an inflection in the titration curve was found to be a practical means of determining their total acidity. This method, however, could not be successfully applied to organic soils. Titration with sodium and calcium hydroxides in the presence or absence of sodium chloride solution gave the same results in the case of the few soils used in preliminary work. However, with sodium hydroxide it was necessary to allow a period greater than 24 hours for the establishment of equilibrium.

2. The values obtained by titration were in substantial agreement with the results given by two other methods, namely, the modified method of Hissink and the indirect method of Page and Williams. It is suggested that these methods be used as alternative methods in determining the total acidity of soils when a satisfactory inflection in the titration curve can not be obtained. The method of Page and 
Williams, which is based on the principle of base exchange, is shown to be well adapted to measuring the acidity of organic soils.

\section{ACKNOWLEDGMENT}

The writer is indebted to Robert $\mathrm{B}$. Hobbs for the determinations of acidity made by the several methods.

Washington, December 12, 1932. 